\title{
Canine visceral leishmaniasis in Rondônia, Brazil: a report of an autochthonous case
}

\author{
Leishmaniose visceral canina em Rondônia: relato de um caso autóctone \\ Henrique Momo Ziemniczak ${ }^{1}$ (D), Guilherme Henrique Lemes da Silva ${ }^{1}\left(\mathbb{D}\right.$, Maerle Oliveira Maia ${ }^{1}$ (D),

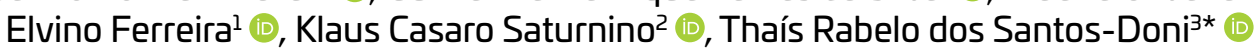

\begin{abstract}
Visceral Leishmaniasis (VL), also known as kala-azar, is a disseminated protozoan infection caused by the Leishmania donovani complex. Traditionally, the definitive diagnosis is made by detecting amastigotes in biological tissue samples. In August 2015, an apparently healthy, young adult, female, mongrel dog from the Zoonosis Control Center of the Rolim de Moura, Rondônia, was subjected to the canine visceral leishmaniasis diagnosis. The diagnosis was conducted using bone marrow aspirate smears and popliteal lymph node smears by Fine-needle aspiration biopsy (FNAB); stained slides with Diff-Quick screened for Leishmania amastigotes by means of direct optical microscopic examination (100x). Lymph node and bone marrow aspirates were used to investigate the presence of Leishmania infantum chagasi DNA by real-time PCR. The popliteal lymph node positive result was observed in typical amastigotes, presenting nucleus and kinetoplasts associated with lymphoblastic proliferation, reactive macrophages, plasmocytes (commonly Mott cells), eosinophils, and lymphoglandular hyperplasia. A positive bone marrow sample resulted from the observation of amastigotes in the monocyte cytoplasm or free on the smear background. The presence of the L. infantum $\mathrm{kDNA}$ was detected in lymph node and bone marrow FNAB samples. This research note describes the autochthonous case of CVL recorded in the state of Rondônia, Brazil, a nonendemic area for VL. According to the data, future studies must include a larger number of animals to elucidate the parasite's epidemiological resource in Rondônia.
\end{abstract}

KEYWORDS: Leishmania, Cytology, PCR, lymph node, dog.

RESUMO: A Leishmaniose visceral (LV), também conhecida como kala-azar, é uma infecção disseminada por protozoários causada pelo complexo Leishmania donovani. Tradicionalmente, o diagnóstico definitivo é feito pela detecção de amastigotas no tecido. Em agosto de 2015, uma cadela, vira-lata, com idade superior a 2 anos, aparentemente saudável, do Centro de Controle de Zoonoses do Rolim de Moura / RO, foi submetida ao diagnóstico de CVL usando esfregaços de aspirado de medula óssea e linfonodos poplíteos por biópsia aspirativa por agulha fina (PAAF), lâminas coradas com Diff-Quick rastreado para amastigotas de Leishmania por meio de exame microscópico óptico direto $(100 \times)$. Os aspirados de linfonodos e medula óssea foram investigados quanto a presença de DNA de L. infantum por PCR em tempo real. O resultado positivo dos linfonodos poplíteos foi demonstrado pela observação de amastigotas típicos, apresentando núcleo e cinetoplasto, associados à proliferação linfoblástica, macrófagos reativos, plasmócitos (não raramente células Mott), eosinófilos e hiperplasia linfoglandular. Amostras positivas de medula óssea resultaram da observação de amastigotas no citoplasma de monócitos ou livres no fundo do esfregaço. A presença do kDNA de L. infantum foi detectada em amostras de FNAB de linfonodo e medula óssea. Esta nota de pesquisa descreve o caso autóctone de CVL registrado no estado de Rondônia (RO), Brasil, área não endêmica de Leishmaniose visceral. Portanto, de acordo com os dados revelados, serão necessários estudos que incluam um número maior de animais para elucidar a característica epidemiológica do Leishmania em Rondônia, Brasil.

PALAVRAS-CHAVE: Leishmania, citologia, PCR, nódulos linfáticos, cão.

\section{INTRODUCTION}

Leishmaniasis is a tropical disease included among the neglected diseases affecting the poorest populations of developing countries. Leishmaniasis is caused by an intracellular protozoon of Leishmania; the vectors are phlebotomine sandflies. The disease occurs widely in tropical and subtropical areas and can be found in 98 countries in America (North, Central, South), Africa, Europe, and Asia. Visceral leishmaniasis (VL) is endemic in 62 countries, and 200 million people are at risk. New cases are estimated at around 
500,000 annually worldwide and the disease could be fatal if appropriate treatment is not provided (ALVAR; VELEZ; BERN; HERRERO et al., 2012; WHO, 2019).

According to the Pan American Health Organization/ World Health Organization (2019), from 2016 to 2017, there was an increase of $28.5 \%$ (914) of cases in Brazil, with an incidence of 1.98 cases per 100,000 inhabitants. Northeast Brazil is even more affected, but regions that were previously not affected have reported recent cases, such as in southern Brazil (WHO, 2019). The epidemiology underscores the seriousness of the situation and the geographic expansion of $\mathrm{VL}$, a neglected disease with a high degree of lethality; there is a greater occurrence in populations with poor conditions of sanitation, housing, unplanned urban occupation, and favorable climate, which facilitates the presence of the vector (WERNECK, 2010).

Leishmania infantum chagasi (synonymous with Leishmania chagasi; Kinetoplastida: Trypanosomatidae) is the etiological agent of zoonotic VL in Asia, Africa, and Europe and in Central and South America (MAIA; CARDOSO, 2015).

Domestic dogs (Canisfamiliaris) are considered the major hosts of this parasite and the main reservoirs for zoonotic human VL, which is potentially lethal if left untreated (PENNISI, 2015). The Ethics Committee on Animal Experimentation, UNIR of the May 4, 2014 - Protocol No. PP 010/2014, approved this study.

\section{CASE REPORT}

In August 2015, an apparently healthy, young adult, mongrel female dog, born and raised in the city of Rolim de Moura, Rondônia (RO), Brazil, was admitted to the Zoonosis Control Center of the Rolim de Moura. The dog it was subjected to the CVL diagnosis using bone marrow aspirate smears and popliteal lymph node smears by Fine-needle aspiration biopsy (FNAB); the smears were stained with Diff-Quick and screened for Leishmania spp. amastigotes by direct optical microscopic examination (100x).

DNA extraction was performed on lymph node and bone marrow FNAB that were stored in propylene tubes. Samples were washed with PBS solution and centrifuged at $12,000 \times \mathrm{g}$ for 10 minutes, followed by SCC (Sodium Citrate Solution) washing for five minutes at $14,000 \times \mathrm{g}$. A lysis buffer $(375$ $\mathrm{mL}$ of $0.2 \mathrm{M}$ sodium acetate, $25 \mathrm{~mL}$ of $10 \%$ sodium dodecylsulfate, and $5 \mathrm{~mL}$ of $20 \mathrm{mg} / \mathrm{mL} \mathrm{K}$ proteinase) was added to the pellets, followed by overnight incubation at $37.8^{\circ} \mathrm{C}$. The lysates were treated with phenol/chloroform/isoamyl alcohol (25:24:1); DNA was precipitated with ethanol, dried, and resuspended in $200 \mathrm{~mL}$ of TE buffer. DNA was stored at $-20{ }^{\circ} \mathrm{C}$ until real-time PCR was performed. PCR analyses were carried out using the Step One Plus ${ }^{\circledR}$ Real-Time PCR System (Applied Biosystems Laboratories, Foster City, CA, USA). The PCR reactions contained $20 \mu \mathrm{M}$ of each primer (Leish 1: 5'-AACTTTTCTGGTCCTCCGGGTAG-3'and
Leish2: 5'-ACCCCCAGTTTCCCGCC-3'), $10 \mu \mathrm{M}$ of the TaqMan Probe (FAM-5'-AAAAATGGGTGCAGAAAT-3'MGB) (FRANCINO et al., 2006), and the iTaq Universal Probes Supermix (BioRad, USA). In the thermocycler, samples were submitted to one incubation step at $50^{\circ} \mathrm{C}$ for $2 \mathrm{~min}$ and an initial denaturation step at $95^{\circ} \mathrm{C}$ for $10 \mathrm{~min}$, followed by 40 cycles at $95^{\circ} \mathrm{C}$ for $15 \mathrm{~s}$ and $60^{\circ} \mathrm{C}$ for $1 \mathrm{~min}$.

The popliteal lymph node positive result was observed in typical amastigotes, presenting nucleus and kinetoplast (Figure 1) associated with lymphoblastic proliferation, reactive macrophages, plasmocytes (commonly Mott cells), eosinophils, and lymphoglandular hyperplasia. A positive bone marrow sample resulted from the observation of amastigotes in the monocyte cytoplasm or free on the smear background.

The samples were evaluated by qPCR using the Leish-1 and Leish-2 primers, which amplify a fragment of the kinetoplast DNA ( $\mathrm{kDNA}$ ) minicircle of the parasite. The presence of the L. infantum $\mathrm{kDNA}$ was detected in lymph node and bone marrow FNAB samples.

\section{DISCUSSION AND CONCLUSIONS}

This research note describes an autochthonous case of CVL recorded in the state of Rondônia (RO), Brazil, a non-endemic area for visceral leishmaniasis.

Leishmaniasis can be zoonotic, transmitted between animals and humans or anthroponotic, in which humans represent the only reservoir and the person-to-person transmission occurs through the bite of the infected vector (ALVAR; VELEZ; BERN; HERRERO et al., 2012).

In Canine Visceral Leishmaniasis (CVL) diagnostics, it is difficult to find a highly sensitive method to correctly diagnose cases with only a few parasites in the material. The diagnosis of CVL can be difficult due to the complex pathogenesis and broad spectrum of clinical and clinical-pathological findings. The clinical signs are nonspecific, and confirmation by a specific laboratory or parasitological diagnosis is required. The necessary tests that must be included in the diagnostic protocol may vary according to the case presentation and

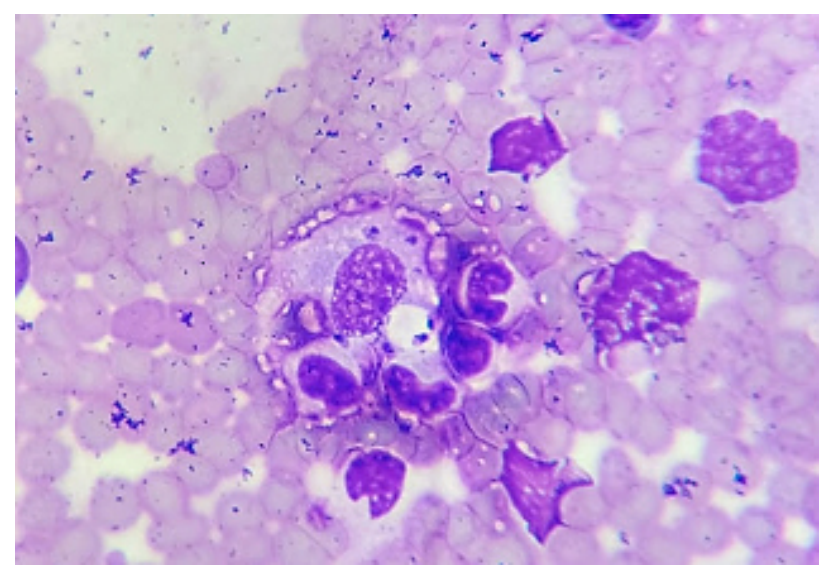

Figure 1. Lymph node cytology containing amastigote forms of Leishmania. Diff-Quick. Magnification of 100x. 
epidemiological scenario. The immunosuppression caused by the disease facilitates opportunistic infections, which can make the diagnosis even more difficult.

The tests for confirming the diagnosis are classified as direct or indirect. Direct tests confirm the presence of the parasite or its components; indirect tests demonstrate the host's response to the parasite. It is important to emphasize that a positive indirect test, such as serology, may or may not indicate that an infection is present, while a positive direct test, such as cytology or CRP, indicates only infection by Leishmania spp., but not necessarily that it has advanced to the disease state.

The presence of circulating antibodies does not necessarily indicate that a dog has the clinical manifestation of the disease, and the presence of amastigotes can be seen in healthy immunocompetent dogs. Therefore, the "Canine Leishmaniasis Working Group" (CLWG) suggests a combination of clinical data and laboratory tests to differentiate animals into groups of exposed, infected, diseased, severely diseased individuals (PALTRINIERI; GRADONI; ROURA; ZATELLI et al., 2016; PALTRINIERI; SOLANO-GALLEGO; FONDATI; LUBAS et al., 2010).

The parasitological diagnosis is the most reliable method; it is based on the demonstration of the parasite obtained from aspiration biopsy liver, lymph nodes, spleen, bone marrow, and skin biopsy or scarification. It is a safe method of diagnosis since the positive result is given by direct observation of amastigotes. This study considered the demonstration of amastigotes in a stained smear as the "gold standard."

Lymph node and bone marrow FNAB smears stained with Romanovsky stains are used routinely for CVL diagnosis, despite having lower sensitivity than other methods. FNAB smears permit the direct search for protozoal amastigotes and lymphoid tissue cellularity (SANTOS; CARREIRA; FERRARI; MOREIRA et al., 2014).

The specificity of FNAB smears is approximately $100 \%$, but depends on the degree of parasitemia, type of biological material collected, and blade scanning time; the sensitivity can be around $80 \%$ for symptomatic dogs and lower for asymptomatic dogs (SANTOS; CARREIRA; FERRARI; MOREIRA et al., 2014). Conventional PCR, nested PCR, and real-time PCR techniques are widely used in the clinical routine for detecting parasite DNA (SOLANO-GALLEGO; KOUTINAS; MIRO; CARDOSO et al., 2009). The detection of Leishmania infantum chagasi indicates that the dog is infected. The differentiation between infected and sick must be made in correlation with the presence or absence of clinical and laboratory changes (PALTRINIERI; GRADONI; ROURA; ZATELLI et al., 2016).

According to the Brazilian Ministry of Health, in 2013, 1,094 cases of cutaneous leishmaniasis were reported in humans in Rondônia, confirming the importance of this infection in the western Amazonian region of Brazil (BRASIL, 2013).
The presence of the phlebotomine sand fly Lutzomyia longipalpis (GIL; BASANO; SOUZA; SILVA et al., 2003) in this region suggests that there is a risk and that visceral leishmaniasis could become endemic in Rondônia.

The first confirmation of antibodies against Leishmania spp. in dogs from Monte Negro, Rondônia was performed by AGUIAR; OLIVEIRA; CAVALCANTE; LABRUNA $e t$ al. (2010).

This study confirmed the presence of CVL by observation of typical amastigotes in Rondônia, a non-endemic area for visceral leishmaniasis. This supports other research conducted in the Western Amazon that suggests the presence of CVL.

An important epidemiological feature that has been observed in South America is that the majority of the dogs infected by $L$. infantum are apparently healthy, exhibiting no visible clinical signs of visceral leishmaniasis (OTRANTO; PARADIES; DE CAPRARIIS; STANNECK et al., 2009). In some foci in Brazil, over $80 \%$ of the seropositive dogs might be clinically healthy (QUEIROZ; MONTEIRO; MACEDO; ROCHA et al., 2009). The results in the present study support these findings.

Dogs in the exposed group are those that do not show clinical signs, have positive serology with low titers, and are negative for PCR or cytology (PALTRINIERI; GRADONI; ROURA; ZATELLI et al., 2016). The animals in the infected group also do not show clinical signs, have normal hematological values, and varying serum biochemistry, but exhibit PCR- or cytology-positive results in bone marrow, lymph nodes, spleen, skin, or peripheral blood. The dogs in the sick group are the same as those in the infected group, but display clinical signs. The animals in the severely ill group are the same as the sick animals, but with severe clinical conditions.

This information might be relevant because but apparently healthy dogs that are seropositive can also serve as a source of infection to phlebotomine sandflies (MICHALSKY; ROCHA; DA ROCHA LIMA; FRANCA-SILVA et al., 2007). Although the prevalence of Leishmania infantum chagasi. infection in dogs in South America can vary widely from region to region and according to the diagnostic method used, it is usually over 25\% (ROMERO; LÓPEZ; ECHEVERRY; RIVAS, 2008) and might be as high as 75\% in highly endemic foci (CORTADA; DOVAL; SOUZA LIMA; OSHIRO et al., 2004).

According to THOMAZ-SOCCOL; CASTRO; NAVARRO; FARIAS et al. (2009), the migration of such animals can disseminate the parasite to other regions, provided the agent finds an adequate ecotope and a specific vector (Lutzomyia longipalpis). The results reported here necessitate studies including a larger number of animals to elucidate the epidemiological feature of the parasite in northern Brazil, and specifically in Rondônia. 


\section{REFERENCES}

AGUIAR, D. M.; OLIVEIRA, T. M.; CAVALCANTE, G. T.; LABRUNA, M. B. et al. Seroprevalence of anti-Leishmania spp. antibodies in rural dogs from the city of Monte Negro, State of Rondonia, Brazil. Rev Bras Parasitol Vet, 19, n. 1, p. 71-72, Jan-Mar 2010.

ALVAR, J.; VELEZ, I. D.; BERN, C.; HERRERO, M. et al. Leishmaniasis worldwide and global estimates of its incidence. PLoS One, 7, n. 5, p. e35671, 2012.

BRASIL. Situação epidemiológica da Leishmaniose Tegumentar (LT). Z., S. d. A. a. : Ministério da Saúde. Brasília, DF 2013.

CORTADA, V. M. C. L.; DOVAL, M. E. C.; SOUZA LIMA, M. A. A.; OSHIRO, E. T. et al. Canine visceral leishmaniosis in Anastácio, Mato Grosso do Sul state, Brazil. Vet Res Commun, 28, p. 365-374, 2004.

GIL, L. H.; BASANO, S. A.; SOUZA, A. A.; SILVA, M. G. et al. Recent observations on the sand fly (Diptera: Psychodidae) fauna of the State of Rondonia, Western Amazonia, Brazil: the importance of Psychdopygus davisi as a vector of zoonotic cutaneous leishmaniasis. Mem Inst Oswaldo Cruz, 98, n. 6, p. 751-755, Sep 2003.

MAIA, C.; CARDOSO, L. Spread of Leishmania infantum in Europe with dog travelling. Vet Parasitol, 213, n. 1-2, p. 2-11, Sep 302015 .

MICHALSKY, E. M.; ROCHA, M. F.; DA ROCHA LIMA, A. C.; FRANCASILVA, J. C. et al. Infectivity of seropositive dogs, showing different clinical forms of leishmaniasis, to Lutzomyia longipalpis phlebotomine sand flies. Vet Parasitol, 147, n. 1-2, p. 67-76, Jun 202007.

OTRANTO, D.; PARADIES, P.; DE CAPRARIIS, D.; STANNECK, D. et al. Toward diagnosing Leishmania infantum infection in asymptomatic dogs in an area where leishmaniasis is endemic. Clin Vaccine Immunol, 16, n. 3, p. 337-343, Mar 2009.

PALTRINIERI, S.; GRADONI, L.; ROURA, X.; ZATELLI, A. et al. Laboratory tests for diagnosing and monitoring canine leishmaniasis. Vet Clin Pathol, 45, n. 4, p. 552-578, Dec 2016.

PALTRINIERI, S.; SOLANO-GALLEGO, L.; FONDATI, A.; LUBAS, G. et al. Guidelines for diagnosis and clinical classification of leishmaniasis in dogs. J Am Vet Med Assoc, 236, n. 11, p. 1184-1191, Jun 12010.

PENNISI, M. G. Leishmaniosis of companion animals in Europe: an update. Vet Parasitol, 208, n. 1-2, p. 35-47, Feb 282015.

QUEIROZ, P. V.; MONTEIRO, G. R.; MACEDO, V. P.; ROCHA, M. A. et al. Canine visceral leishmaniasis in urban and rural areas of Northeast Brazil. Res Vet Sci, 86, n. 2, p. 267-273, Apr 2009.

ROMERO, M. H.; LÓPEZ, M. C.; ECHEVERRY, M. C.; RIVAS, F. A. Leishmaniasis visceral canina: pruebas diagnósticas no identifican estados reales de la infección. Rev Salud Publica Bogota 10, p. 290-298, 2008.

SANTOS, T. R.; CARREIRA, V. S.; FERRARI, H. F.; MOREIRA, M. A. et al. Comparison of PCR with stained slides of bone marrow and lymph nodes aspirates with suspect diagnosis for leishmaniasis. Acta Trop, 140, p. 137-140, Dec 2014.

SOLANO-GALLEGO, L.; KOUTINAS, A.; MIRO, G.; CARDOSO, L. et al. Directions for the diagnosis, clinical staging, treatment and prevention of canine leishmaniosis. Vet Parasitol, 165, n. 1-2, p. 1-18, Oct 282009.

THOMAZ-SOCCOL, V.; CASTRO, E. A.; NAVARRO, I. T.; FARIAS, M. R. d. et al. Casos alóctones de leishmaniose visceral canina no Paraná, Brasil: implicações epidemiológicas. Revista Brasileira de Parasitologia Veterinária, 18, p. 46-51, 2009.

WERNECK, G. L. Expansão geográfica da leishmaniose visceral no Brasil. Cad. Saúde Pública, 26, n. 4, p. 644-645, 2010.

WHO. SisLeish-PAHO/WHO. Washington, D.C., United States of America: World Health Organization/Pan American Health Organization 2019. 